Article

\title{
Efficient Dye-Sensitized Solar Cells Composed of Nanostructural ZnO Doped with Ti
}

\author{
Mati Ur Rahman ${ }^{1,2}$, Mingdeng Wei ${ }^{1,2, *}$, Fengyan Xie ${ }^{1,2}$ and Matiullah Khan ${ }^{3, *}$ (D) \\ 1 State Key Laboratory of Photocatalysis on Energy and Environment, Fuzhou University, \\ Fuzhou 350002, China; matiurrahman617@yahoo.com (M.U.R.); asifncp@yahoo.com (F.X.) \\ 2 Institute of Advanced Energy Materials, Fuzhou University, Fuzhou 350002, China \\ 3 Department of Physics, Kohat University of Science and Technology, Kohat 26000, Pakistan \\ * Correspondence: wei-mingdeng@fzu.edu.cn (M.W.); matiullahustb@gmail.com (M.K.); \\ Tel.: +86-0591-22865057 (M.W.)
}

Received: 27 February 2019; Accepted: 10 March 2019; Published: 17 March 2019

check for updates

\begin{abstract}
Photoanode materials with optimized particle sizes, excellent surface area and dye loading capability are preferred in good-performance dye sensitized solar cells. Herein, we report on an efficient dye-sensitized mesoporous photoanode of $\mathrm{Ti}$ doped zinc oxide (Ti-ZnO) through a facile hydrothermal method. The crystallinity, morphology, surface area, optical and electrochemical properties of the $\mathrm{Ti}-\mathrm{ZnO}$ were investigated using $\mathrm{X}$-ray photoelectron spectroscopy, transmission electron microscopy and $\mathrm{X}$-ray diffraction. It was observed that $\mathrm{Ti}-\mathrm{ZnO}$ nanoparticles with a high surface area of $131.85 \mathrm{~m}^{2} \mathrm{~g}^{-1}$ and a controlled band gap, exhibited considerably increased light harvesting efficiency, dye loading capability, and achieved comparable solar cell performance at a typical nanocrystalline $\mathrm{ZnO}$ photoanode.
\end{abstract}

Keywords: Ti doped $\mathrm{ZnO}$; dye-sensitized solar cell; bandgap energy; photovoltaic performance

\section{Introduction}

Environmental challenges and increasing global energy consumption demand clean and renewable energy to support the activities of modern society [1]. To convert solar energy directly into electricity using solar cells is one of the most feasible technologies. As an alternative to the conventional silicon-based solar cell, dye-sensitized solar cells (DSSCs) have attracted tremendous interest due to their simple fabrication process, low manufacturing cost, and environmentally-friendly advantages [2-6]. Thus far, an extensive study has been carried out on the $\mathrm{TiO}_{2}$ nanoparticle as a photoelectrode since 1991 [7,8], although the $\mathrm{TiO}_{2}$ nanoparticle showed more than $14 \%$ power conversion efficiency when used as a photoanode due to its higher surface area. However, its poor long-term stability and low electron mobility are concerns $[9,10]$. Excluding $\mathrm{TiO}_{2}$, studies on other alternative semiconductor metal oxides, such as $\mathrm{SnO}_{2}, \mathrm{ZnO}, \mathrm{Nb}_{2} \mathrm{O}_{5}$ and $\mathrm{Zn}_{2} \mathrm{SnO}_{4}$, have been conducted [11-19]. Among these, $\mathrm{ZnO}$ has received increasing interest as a promising alternative photoanode material for DSSCs due to similar electron affinities and band gap energy ( $\left.E_{g}\right)$, i.e., $3.2 \mathrm{eV}$ and $3.3 \mathrm{eV}$ compared with $\mathrm{TiO}_{2}$, and has excellent electron diffusivity $[20,21]$. At the same time, $\mathrm{ZnO}$ is probably richer in diverse morphologies compared to any known materials [22-24]. More recently, several studies have focused on the diverse morphology and multidimensionality of $\mathrm{TiO}_{2}$ and $\mathrm{ZnO}$ with regards to robust photocatalytic activity of DSSCs with increasing electron transport and higher surface-to-volume ratios [25-27]. Additionally, $\mathrm{ZnO}$ has amazing merits like stability against photo corrosion, low cost, large excitation binding energy $(60 \mathrm{eV})$, easier synthesis, and surface modification [28]. However, the photovoltaic performance of $\mathrm{ZnO}$-based dye-sensitized solar cells is still poor, which could be caused by the narrow absorption spectral range, the quick recombination 
of photo-generated electron-hole pair occurring in or on the surface photoanode and the instability of film in acidic dye solution in the case of $\mathrm{ZnO}$ materials [29]. In principle, $\mathrm{ZnO}$-based electrodes could achieve a similar or even better photovoltaic performance if the aforementioned drawbacks could be overcome. Up to now, a number of possible strategies have been adopted to tackle these issues of $\mathrm{ZnO}$ electrodes. The morphological surface modification with nanoparticles of noble metals $(\mathrm{Au}, \mathrm{Pt}, \mathrm{Pd}, \mathrm{Ag}$, etc.) has been widely employed to decorate $\mathrm{ZnO}$ by doping to suppress carrier recombination $[30,31]$. The light sensing properties can be improved by passivation of the defect in the bulk material and at the oxide interface with dangling bond fixing [32]. Considering the economic and limited sources of noble metals, in this prospective study, Ti-doped $\mathrm{ZnO}$ and undoped $\mathrm{ZnO}$ nanoparticles were fabricated using a hydrothermal route with the aim to achieve an efficient charge separation, interfacial charge transfer to adsorbed dye to increase lifetime of charge carrier, and enhancing the photovoltaic performance of ZnO-based DSSCs.

\section{Materials and Methods}

\subsection{Synthesis of Materials}

Titanium-doped zinc oxide nanoparticles were synthesized using a facile hydrothermal route. In a typical procedure, $1.25 \mathrm{mmol}$ zinc acetate dihydrate was added to methanol and stirred for $20 \mathrm{~min}$, then $2 \mathrm{mmol}$ of potassium hydroxide $(\mathrm{KOH})$ was dropped to the solution, and a calculated amount ( $\mathrm{Ti}=1,2,5$ and $7.5 \mathrm{wt} \%$ ) of titanium isopropoxide (TTIP) was introduced under continuous stirring. The reaction mixture was further stirred and refluxed at $60-80^{\circ} \mathrm{C}$. The transparent color of the zinc acetate solution changed to transparent white, which indicated the starting of Ti-ZnO synthesis. After several minutes of stirring, the reaction mixture was transferred into a Teflon lined autoclave and kept in oven at $180{ }^{\circ} \mathrm{C}$ for $12-15 \mathrm{~h}$. After cooling to room temperature, the yellowish solution was separated by centrifugation ( $8000 \mathrm{rpm}$ ) for $10 \mathrm{~min}$ and washed several times with absolute ethanol. Eventually, the powder was dried in vacuum at $60{ }^{\circ} \mathrm{C}$ overnight and calcined at $500{ }^{\circ} \mathrm{C}$ for $2 \mathrm{~h}$ in Ar. As a reference sample, the undoped zinc oxide nanoparticles were also synthesized via the same procedure except for the addition of TTIP.

\subsection{Fabrication of Dye-Sensitized Solar Cells}

\subsubsection{Paste Preparation}

Different pastes of $\mathrm{ZnO}$ and titanium-doped zinc oxide ( $\mathrm{Ti}-\mathrm{ZnO}$ ) were prepared according to previously reported literature [33,34]. Typically, ethyl cellulose, $\alpha$-terpineol $(10,5 \%$ by weight) and zinc oxide or Ti-ZnO nanoparticles were suitably dispersed in ethanol using an Ultra-Turrax T25 homogenizer followed by a rotary evaporator to concentrate up to $20 \mathrm{wt} \%$.

\subsubsection{Films Fabrication}

Photoanodes were prepared through a screen printing method with as prepared zinc oxide and Ti-ZnO paste applied on an FTO substrate (sheet resistance $8 \Omega \mathrm{sq}^{-1}$, Pilkington, and followed by sintering at $450{ }^{\circ} \mathrm{C}$ for $30 \mathrm{~min}$.

\subsubsection{Dye Loading}

The dye-loading capability of the photoanodes was estimated photometrically. The $\mathrm{ZnO}$ and Ti doped $\mathrm{ZnO}$ with various percentages of photoanodes loaded with N719 dyes were immersed in $10 \mathrm{mM} \mathrm{NaOH}$ at $30^{\circ} \mathrm{C}$ overnight. The most intense band intensity was the region of 550 to $515 \mathrm{~nm}$ of the adsorption spectrum and was used to calibrate the dye loading. 


\subsubsection{Device Fabrication}

The $\mathrm{Ti}-\mathrm{ZnO}$ and $\mathrm{ZnO}$ electrodes fabricated as described above were immersed in $0.5 \mathrm{mM}$ solution of N719 dye in isopropyl alcohol and acetonitrile $(1: 1 \mathrm{v} / \mathrm{v})$ for $2 \mathrm{~h}$ at $30{ }^{\circ} \mathrm{C}$ and then rinsed with acetonitrile and dried with a nitrogen gas flow. The electrolyte was composed of $0.6 \mathrm{M}$ 1,2-dimethyl-3-n-propylimidazolium iodide (DMPII), $0.05 \mathrm{M} \mathrm{I}_{2}, 0.1 \mathrm{M} \mathrm{LiI}$, in 3-methoxypropinonitrile with $0.5 \mathrm{M}$ 4-tertbutylpyridine (TBP). A counter electrode was fabricated via dropping of $5 \mathrm{mM}$ $\mathrm{H}_{2} \mathrm{PtCl}_{6}$ on a FTO substrate and sintered at $400{ }^{\circ} \mathrm{C}$ for $30 \mathrm{~min}$. Afterwards, a polyethylene spacer was sandwiched between a dye-sensitized photoanode and a Pt counter electrode to prevent the cell from short circuiting. For the last step of DSSC fabrication, the redox electrolyte was injected into the gap of the spacer. $\mathrm{ZnO}$ cells were fabricated for comparison of Ti-ZnO based device photovoltaic performance to a known system.

\subsection{Characterization of the Materials and Measurement of the Photovoltaic Performance}

The phase purity and structural properties of the materials were analyzed by powder $\mathrm{X}$-ray diffraction (XRD) on a Rigaku Ultima IV X-ray diffractometer using $\mathrm{Cu} K \alpha$ radiation $(\lambda=1.5418 \AA$ ). A scanning electron microscope (SEM, Hitachi S4800) was applied to determine the size and morphology, and a transmission electron microscopy (TEM) was performed on a Tecnai G2 F20 (FEI, Hillsboro, OR, USA) transmission electron microscope to further characterize the morphology and intrinsic structure of the materials. The $\mathrm{N} 2$ adsorption-desorption isotherms of Ti-ZnO were performed on an ASAP 2020 surface area analyzer (Micromeritics, Norcross, GA, USA). The film thickness was measured on a profilometer (Accretech Surfcom 130A). A Shimadzu UV-2450 UV-vis spectrophotometer and a Renishaw inVia Raman microscope were used for spectroscopic measurement. The Keithley 2400 SourceMeter under simulated AM 1.5 G illumination (Peccell, with a $1000 \mathrm{~W}$ Xe lamp and AM 1.5 filter) was used to investigate current-voltage (I-V) characteristic. Incident photon-to-current conversion efficiency (IPEC) spectra were recorded on a PEC S-20 (Peccell, Technology Co., Ltd., Yokohama, Japan) multimeter. Electrochemical impedance spectroscopy (EIS) was conducted on the electrochemical workstation IM6 (Zahner, and a bias potential of $-0.7 \mathrm{~V}$ in dark condition with an $80 \mathrm{MHz}-3 \mathrm{kHz}$ range.

\section{Results and Discussion}

The crystallographic phases of $\mathrm{ZnO}$ and $\mathrm{Ti}-\mathrm{ZnO}$ were analyzed from $\mathrm{X}$-ray diffraction patterns, as shown in Figure 1A. All of the diffraction peaks match the standard phase (JCPDS \# 01-079-0207), indicating that the synthesized materials are well crystallized and phase pure hexagonal $\mathrm{ZnO}$. However, slight shifting of the peaks to a higher angle was observed for titanium-containing materials, $\mathrm{Ti}(7.5 \%)-\mathrm{ZnO}$ compared with the $\mathrm{ZnO}$, which implied the inward relaxation of the lattice due to the substitution of the bigger $\mathrm{Zn}^{2+}$ atom (ionic radius $=0.74 \AA$ ) with smaller ion $\left(\mathrm{Ti}^{4+}\right.$ ionic radius $=0.68 \AA$ ) which had larger size as ions in the crystalline structure, and caused a change in the lattice parameter value without changing the crystal structure of the $\mathrm{ZnO}$ lattice. The average value of crystallite size and strain estimated by the Debye-Scherrer equation, $\mathrm{D}=\mathrm{K} \lambda / \beta \operatorname{Cos} \theta[35]$, and the $\mathrm{XRD}$ patterns of all samples are shown in Figure S2 and their physiochemical characteristics, including surface area, strain, crystallite and pore size, are summarized in Table S1.

Two small negligible peaks were found at 25 and 27 degrees with higher dopant concentrations, which may mean that trace amount of $\mathrm{Ti}$ was converted into $\mathrm{TiO}_{2}$ which was not detected by any other characterization technique. The chemical state of the atoms on the surface of $\mathrm{ZnO}$ and the elemental composition were examined via XPS measurements. Figure 1B represents the XPS survey spectra of $\mathrm{ZnO}$ and Ti-ZnO. The well defined peaks centered at 1044, 1021, 531, 475, 459, 285, 140, 98 and $10 \mathrm{eV}$ are ascribed to the binding energy of Zn2 $\mathrm{p}_{1 / 2}, \mathrm{Zn} 2 \mathrm{p}_{3 / 2}, \mathrm{O} 1 \mathrm{~s}, \mathrm{ZnLMM1}, \mathrm{Ti2} \mathrm{p}, \mathrm{C} 1 \mathrm{~s}, \mathrm{Zn} 3 \mathrm{~s}, \mathrm{Zn} 3 \mathrm{~d}$ and $Z n 3 p$ respectively. The high-resolution spectra of $Z n 2 p$ and Ti2P with different dopant consideration are shown in Figure 1C,D. The morphological changes and particle size of the synthesized $\mathrm{ZnO}$ 
with controllable titanium doping concentration were observed by SEM measurements. The SEM images shown in Figure 2A,B prove that the prepared $\mathrm{ZnO}$ and $\mathrm{Ti}-\mathrm{ZnO}$ samples were composed of nanoparticles with particle sizes of ca. 9-13 $\mathrm{nm}$, while the incorporation of the doping particle did not induce any significant change in their morphology but decreased the particle size. The typical crystalline behavior, morphology and $\mathrm{Ti}$ ion distribution in the $\mathrm{ZnO}$ crystal lattice are further confirmed from TEM images depicted in Figure 2C,D. The corresponding TEM images reveal that the obtained materials were well crystallized, and the selected area electron diffraction (SAED) pattern inset in Figure 2C indicates ((101), (102) and (110)) a well-crystalized plane of ZnO. In addition, the lattice distance $0.24 \mathrm{~nm}$ shown in Figure 2D matches with the (101) plane $\mathrm{ZnO}$ crystal (slightly decrease of pure $\mathrm{ZnO}: 0.25 \mathrm{~nm}$ ), indicating that $\mathrm{Ti}$ ions were evenly distributed in $\mathrm{ZnO}$ crystal lattice.
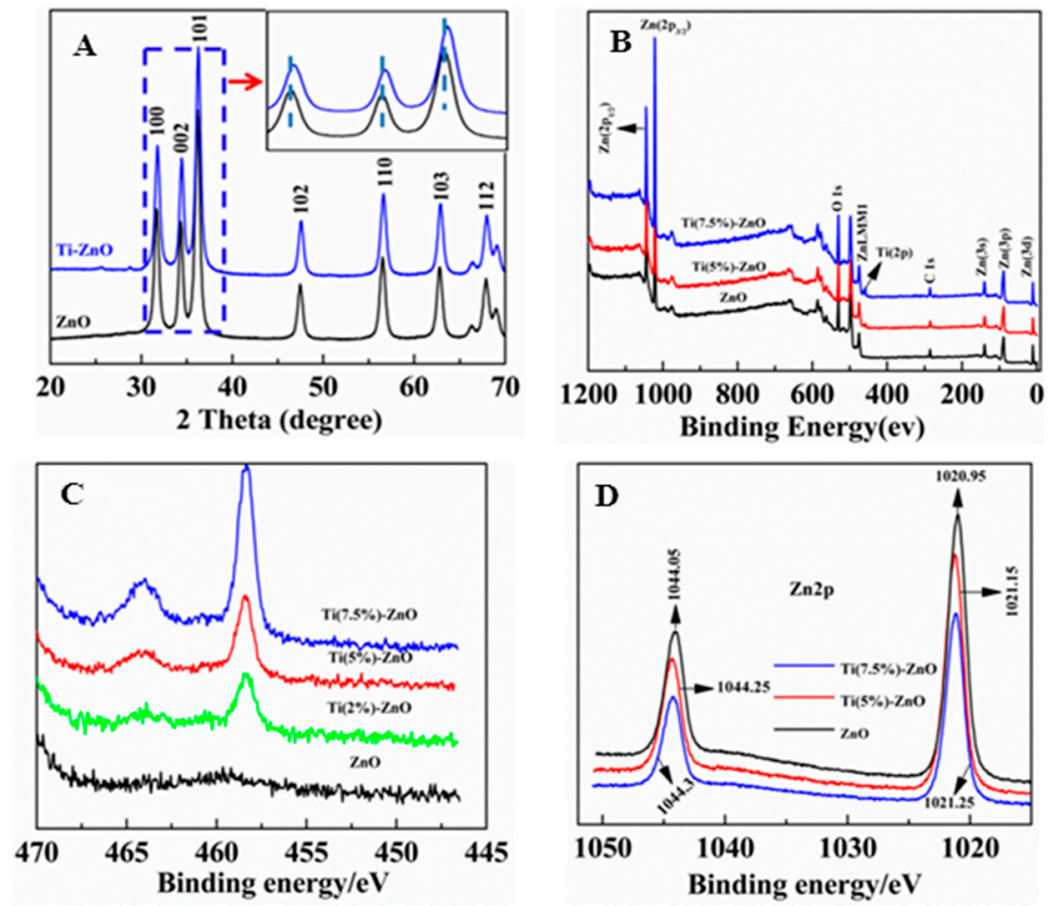

Figure 1. X-ray diffraction patterns of $\mathrm{ZnO}$ and $\mathrm{Ti}(7.5 \%)-\mathrm{ZnO}$, (A) XPS spectra of $\mathrm{ZnO}$ and $\mathrm{Ti}-\mathrm{ZnO}$, (B) survey spectra, (C) high-resolution spectra of Ti2p, and (D) Zn2p respectively.
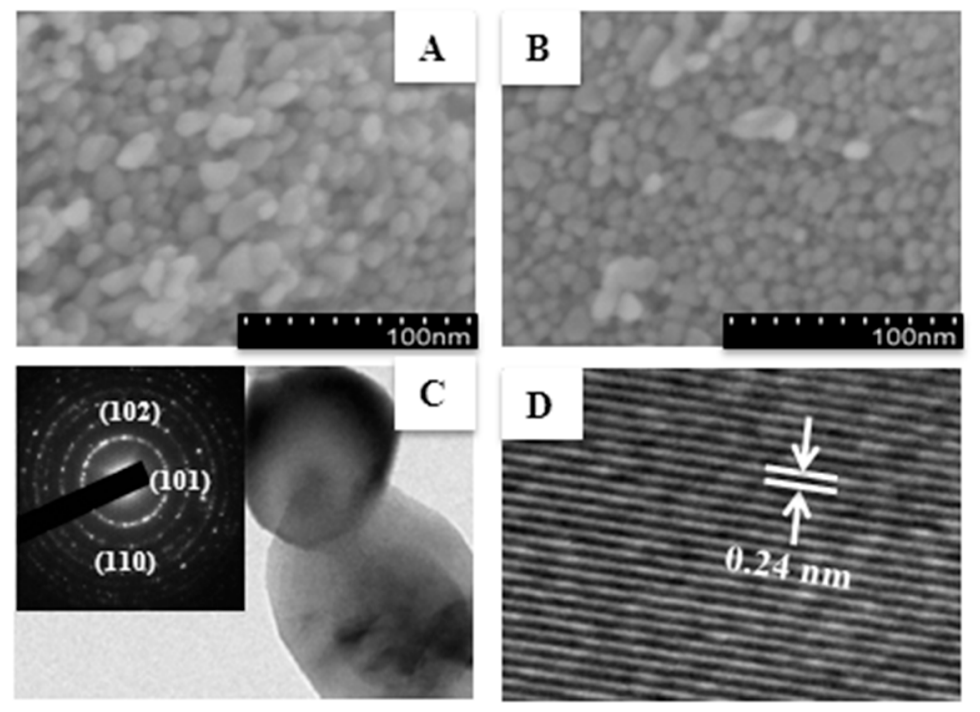

Figure 2. SEM images of (A) ZnO, (B) Ti-ZnO, (C) TEM, images of Ti-ZnO, and (D) HRTEM image of Ti-ZnO. 
The surface area and pore size distribution of $\mathrm{ZnO}$ and $\mathrm{Ti}-\mathrm{ZnO}$ nanoparticles were performed with Brunauer-Emmett-Teller (BET) by using N2 adsorption-desorption isotherm. The XRD and BET results were in good alignment. From the results in Figure 3 and Table S1, it confirms that the surface area of (Ti- $\mathrm{ZnO}$ ) under the same synthetic conditions dramatically increased from 45.38 to $131.85 \mathrm{~m}^{2} \mathrm{~g}^{-1}$ and the average pore size distribution of $\mathrm{Ti}-\mathrm{ZnO}(3.4 \mathrm{~nm})$ was slightly greater compared to $\mathrm{ZnO}(2.8 \mathrm{~nm})$. The increment in BET surface area and pore size may be due to the inhibition of the $\mathrm{ZnO}$ crystallites growth with the incorporation of Ti dopant. The smaller size of Ti-ZnO would possess of higher BET surface area and larger pore size according to the small size effect of nanomaterials. The higher BET surface area and larger pore size would contribute to the higher dye loading, leading to enhanced light harvesting efficiency.

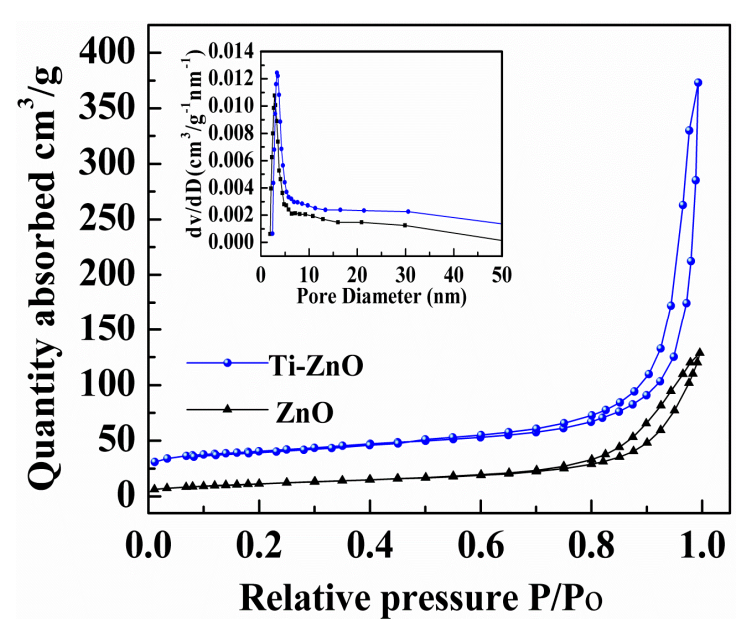

Figure 3. $\mathrm{N}_{2}$ adsorption-desorption isotherms and pore size distribution (inset) of $\mathrm{Ti}-\mathrm{ZnO}$ and $\mathrm{ZnO}$ nanoparticles.

The doped materials were further analyzed for elemental percentage of titanium in $\mathrm{Ti}-\mathrm{ZnO}$ samples via ICP-OES, the data are summarized in Table 1. The ICP-OES analytical and EDS data are in best alignment with calculated values as observed from the ICP-OES analytical results and EDS spectra depicted in Figure S2.

Table 1. Elemental analysis of Ti percentage in Ti-ZnO samples.

\begin{tabular}{cccc}
\hline S/No & Sample Name & Titanium (\%) & \\
\hline & & Calculated & Observed \\
\hline 1 & $\mathrm{Ti}(1 \%)-\mathrm{ZnO}$ & 1.0 & 0.96 \\
2 & $\mathrm{Ti}(2 \%)-\mathrm{ZnO}$ & 2.0 & 1.84 \\
3 & $\mathrm{Ti}(5 \%)-\mathrm{ZnO}$ & 5.0 & 4.71 \\
4 & $\mathrm{Ti}(7.5 \%)-\mathrm{ZnO}$ & 7.5 & 7.23 \\
\hline
\end{tabular}

UV-visible characterization is a significant technique to assess the quantum confinement effects and band gap. In order to analyze the optical changes (effect of doping on the band gap), the UV absorption spectra were measured at room temperature in the range of 200 to $800 \mathrm{~nm}$ as displayed in Figure 4, the broad absorption band at $399 \mathrm{~nm}$ in $\mathrm{ZnO}$ was shifted to a higher wavelength of $426 \mathrm{~nm}$ with incorporation of $\mathrm{Ti}$, which was assigned to the ligand-metal-charge transfer in the octahedral environment. After the successive incorporation of $\mathrm{Ti}$, the resultant products showed more visible light absorbance (visible light utilizing efficiency) compared to pure $\mathrm{ZnO}$, which might be attributable to the fact that the light scattering effect of $\mathrm{ZnO}$ was enhanced by Ti doping. Meanwhile, the decrease in bandgap, was well corresponded to the visible spectrum. The bandgap energy $\left(E_{g}\right)$ was calculated from UV-visible spectrum using Equation (1). 


$$
\mathrm{E}_{\mathrm{g}}=1240 / \lambda
$$

where $\lambda$ is the wavelength measured from UV-visible absorption spectra Figure 4. The Ti-ZnO possesses a narrow forbidden Eg of $2.91 \mathrm{ev}$, is well corresponding to higher visible light harvesting efficiency, which is conductive to produce more photo-generated electrons and enhancement of short current density, as confirmed from IPCE measurement. The valence (VB) and conduction bands $(\mathrm{CB})$ were estimated from oxidation potential $\left(\mathrm{E}_{\mathrm{ox}}\right)$ by cyclic voltammetry (Figure S4) through equations in literature [36]. The corresponding results were manifested in Table S3. Based on optical and electrochemical properties comparison, the band positions of dye N719 and Ti-ZnO are in good alignment which is very important for charge separation. In the DSSC, the dye-sensitized dye adsorbs the photon under solar illumination at its interface, then separation of charge take place at the interface. Due to the well-aligned band positions for the charge separation, the photo-generated electrons can be quickly transferred from excited dye to the conduction band of Ti-ZnO, and the external circuit resulting in the photocurrent. The LUMO level of the N719 dye is higher than that of Ti-ZnO and ZnO, so for the electron transport has a single directional pathway.

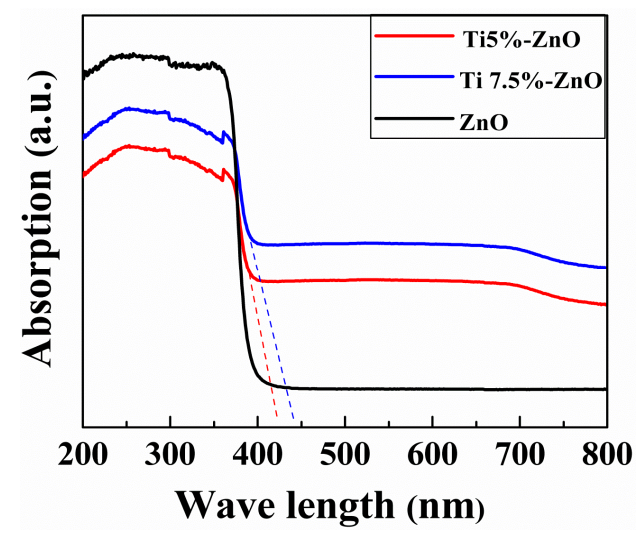

Figure 4. UV-Visible absorption spectra of the $\mathrm{Ti}(5 \%)-\mathrm{ZnO}, \mathrm{Ti}(7.5 \%)-\mathrm{ZnO}$ and $\mathrm{ZnO}$ nanoparticles.

Raman spectroscopy is a sensitive technique for the analysis of subtle phase information, structural defects and crystallinity. $\mathrm{ZnO}$ has a hexagonal wurtzite structure with C6vP63mc space group, the group theory predicts that the Raman spectra of $\mathrm{ZnO}$ has two A1, two E2, two E1 and two B1 modes. To further study the crystallinity and effect of $\mathrm{Ti}$ in the framework structure of $\mathrm{ZnO}$, both the Raman spectra of pure $\mathrm{ZnO}$ and $\mathrm{Ti}-\mathrm{ZnO}$ were performed as shown in Figure 5. From the comparison of Raman spectra, it is evident that the well resolved peaks (TO, E2 and LO phonon modes) small frequency shifting, broadening and intensity decrease in the Ti-ZnO sample might be ascribed to the disorder induced defects or oxygen vacancies and crystal lattice distortion [37].

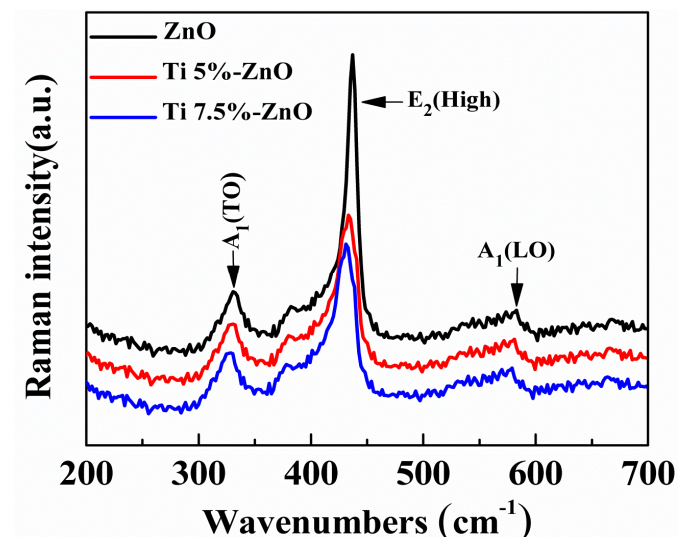

Figure 5. Raman spectra of the $\mathrm{Ti}(5 \%)-\mathrm{ZnO}, \mathrm{Ti}(7.5 \%)-\mathrm{ZnO}$ and pure $\mathrm{ZnO}$ nanoparticles. 
To determine the photovoltaic performance of $\mathrm{ZnO}$ and $\mathrm{Ti}-\mathrm{ZnO}$ nanoparticles based DSSCs, three cells were fabricated for comparison. We have checked all the corresponding parameters which affect the power conversion efficiency of the devices like film thickness, dye immersion time, synthesis temperature and morphology of the materials etc. Finally three types of cells that showed high power conversion efficiencies, due to the quality of devices and photoanode films were investigated in this study. Cells were prepared with as synthesized $\mathrm{ZnO}$, $\mathrm{Ti}(5 \%)-\mathrm{ZnO}$, and $\mathrm{Ti}(7.5 \%)-\mathrm{ZnO}$, respectively. The current-voltage curves are plotted in Figure 5 and the corresponding characteristic are summarized in Table 2. It can be observed that the cell composed of pure $\mathrm{ZnO}$ nanoparticles possessed a short-circuit current Jsc of $8.01 \mathrm{~mA} \mathrm{~cm}^{-2}$ and an efficiency of $3.82 \%$. In comparison, higher Jsc and open-circuit voltage Voc along with a PCE of 5.56\% were obtained for the cell composed of $\mathrm{Ti}(7.5 \%)-\mathrm{ZnO}$. The increase in Jsc and Voc might be attributed to improved light harvesting efficiency of the photoanode, compared with the highest PCE value of the cell composed of $\mathrm{ZnO}$, the PCE was increased by $44.7 \%$. As shown in Figure 6 both results (Jsc and IPCE) of the DSSCs based on $\mathrm{ZnO}, \mathrm{Ti}(5 \%)-\mathrm{ZnO}$ and $\mathrm{Ti}(7.5 \%)-\mathrm{ZnO}$ are in good alignment with the results displayed in Table 2.

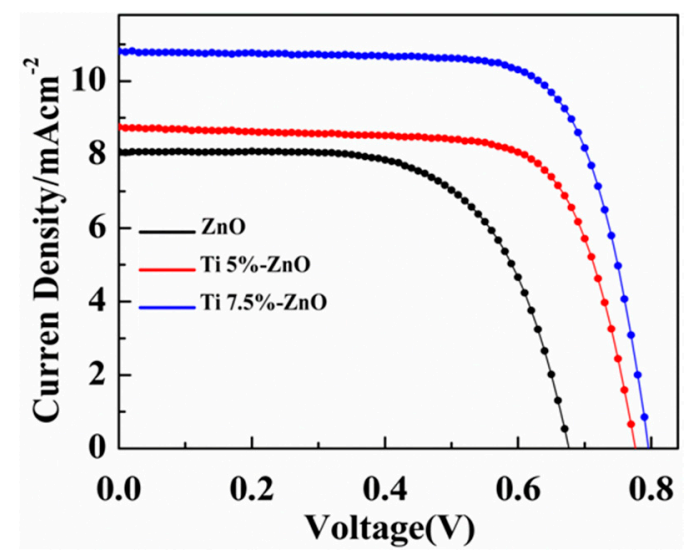

Figure 6. I-V curves of $\mathrm{ZnO}, \mathrm{Ti}(5 \%)-\mathrm{ZnO}$ and $\mathrm{Ti}(7.5 \%)-\mathrm{ZnO}$ nanoparticles based DSSCs, in both the active area is $0.25 \mathrm{~cm}^{2}$ and under (AM 1.5, $100 \mathrm{~mW} / \mathrm{cm}^{-2}$ ) illumination.

Table 2. Photovoltaic performance for the cells composed of $\mathrm{ZnO}$ and $\mathrm{Ti}-\mathrm{ZnO}$ photoanodes

\begin{tabular}{|c|c|c|c|c|c|c|c|}
\hline Cell & Photoanode & $\begin{array}{l}\text { Thickness } \\
(\mu \mathrm{m})\end{array}$ & $\mathrm{Jsc}\left(\mathrm{mA} \mathrm{cm}{ }^{-2}\right)$ & $\mathrm{V}_{\mathrm{oc}}(\mathrm{V})$ & FF & $\eta(\%)$ & $\begin{array}{c}\text { Dye Loading } \\
\left(10^{-7} \mathrm{~mol} / \mathrm{cm}^{2}\right)\end{array}$ \\
\hline 1 & $\mathrm{ZnO}$ & 10.9 & 8.01 & 0.68 & 0.64 & 3.82 & 1.10 \\
\hline 2 & $\mathrm{Ti}(5 \%)-\mathrm{ZnO}$ & 11.1 & 8.90 & 0.77 & 0.65 & 4.45 & 1.34 \\
\hline 3 & $\mathrm{Ti}(7.5 \%)-\mathrm{ZnO}$ & 11.2 & 10.92 & 0.79 & 0.64 & 5.56 & 1.85 \\
\hline
\end{tabular}

All cells show the maximum incident-to-current conversion efficiency (IPCE) percentage at $550 \mathrm{~nm}$ wavelength corresponding to N719 dye adsorption peak as depicted in Figure 7. Furthermore, the adsorption amount of sensitizer dye directly influenced the quantum efficiency of the DSSCs. The IPCE peaks at $550 \mathrm{~nm}$ for $\mathrm{Ti}(7.5 \%)-\mathrm{ZnO}$ is $73.76 \%$, which is higher than $64.37 \%$ for $\mathrm{Ti}(5 \%)-\mathrm{ZnO}$ and $57.23 \%$ for $\mathrm{ZnO}$. In comparison the whole spectral region the $\mathrm{Ti}(7.5 \%)-\mathrm{ZnO}$ showed considerable maximum IPCE value, which might be owing to the fact that $\mathrm{Ti}(7.5 \%)-\mathrm{ZnO}$, with a specific doping concentration of $\mathrm{Ti}$, and narrow forbidden gap of $\mathrm{Eg}$, increased the surface area and dye loading which directly influenced visible light absorbance and utilizing efficiency.

To support the photovoltaic performance enhancement and investigate the charge-transfer mechanism, the cells were analyzed via electrochemical impedance spectroscopy (EIS) under dark condition with $-0.7 \mathrm{~V}$ applied voltage, their Nyquist plots are shown in Figure 8 and corresponding fitted results are summarized in Table 3. Two well-resolved semi-circles were observed in the measured frequency range. The Rs is ascribed to the photoanode film and FTO contact resistance. The small semicircle $\left(R_{c t 1}\right)$ that lies at high frequency range is described to transport resistance at the interface 
of the counter electrode, while the large semicircle $\left(R_{\mathrm{ct} 2}\right)$ at the low frequency range is charge recombination resistance at the interface of photoanode/electrolyte/dye. As observed from the EIS spectra of $\mathrm{ZnO}$ and Ti- $\mathrm{ZnO}$ cells, the $\mathrm{R}_{\mathrm{ct} 2}$ value increased with doping concentration indicating that the charge recombination resistance at the interface of $\mathrm{ZnO} /$ dye/electrolyte decreased remarkably.

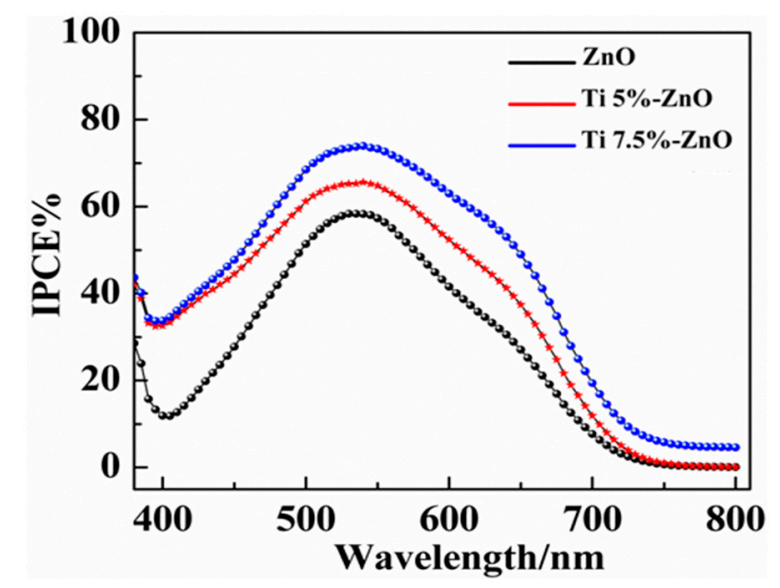

Figure 7. IPCE spectra of the $\mathrm{ZnO}, \mathrm{Ti}(7.5 \%)-\mathrm{ZnO}$ and $\mathrm{Ti}(5 \%)-\mathrm{ZnO}$ nanoparticles based DSSCs.

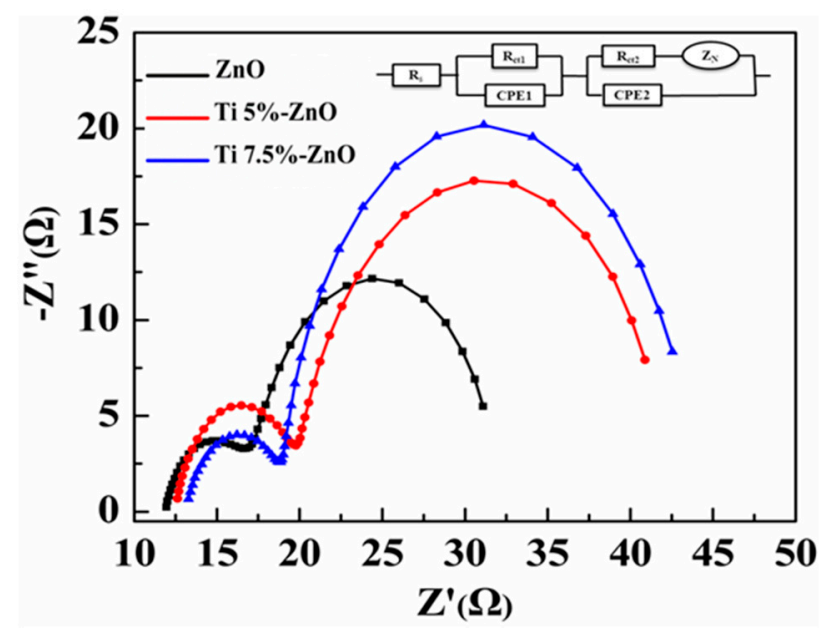

Figure 8. EIS spectra of the cells s composed of $\mathrm{Ti}(7.5 \%)-\mathrm{ZnO}, \mathrm{Ti}(5 \%)-\mathrm{ZnO}$ and $\mathrm{ZnO}$ electrodes.

Table 3. EIS parameters of DSSCs based on $\mathrm{ZnO}$ and Ti-ZnO, with different dopant.

\begin{tabular}{cccccccc}
\hline Cell & Working Electrode & $\mathbf{R}_{\mathbf{s}} / \boldsymbol{\Omega}$ & $\mathbf{R}_{\mathbf{c t} 1}$ & $\mathbf{C P E} 1 / \mathbf{F ~ c m} \mathbf{~ c m}^{-2}$ & $\mathbf{R}_{\mathbf{c t} 2} / \mathbf{\Omega}$ & $\mathbf{C P E} 2 / \mathbf{F ~ c m}^{-2}$ & $\mathbf{Z}_{\mathbf{N}} / \mathbf{\Omega} \mathbf{~ c m}^{-2}$ \\
\hline 1 & $\mathrm{ZnO}$ & 11.31 & 1.31 & $7.80 \times 10^{-4}$ & 31.2 & $4.35 \times 10^{-4}$ & $1.11 \times 10^{-1}$ \\
2 & $\mathrm{Ti}(5 \%)-\mathrm{ZnO}$ & 12.54 & 3.21 & $5.60 \times 10^{-4}$ & 43.5 & $2.09 \times 10^{-3}$ & $2.11 \times 10^{-1}$ \\
3 & $\mathrm{Ti}(7.5 \%)-\mathrm{ZnO}$ & 13.47 & 3.31 & $3.70 \times 10^{-4}$ & 46.4 & $5.25 \times 10^{-4}$ & $2.12 \times 10^{-1}$ \\
\hline
\end{tabular}

Dye instability and carrier recombination in ZnO based DSSCs can occur across both the film-dye interface and film-electrolyte interface. Herein, we have discussed modifying the film/dye/electrolyte interface by way of Ti doping that is conformally doped into the oxide crystal lattice. It is well understood that the Ti doping can improve the $\mathrm{ZnO}$ based dye-sensitized solar cell efficiency by inhibiting the surface recombination of electrons at the film/dye/electrolyte interface by creating an energy barrier for physical separation of electrons. The dye and electrolyte stability of film significantly increases after Ti incorporation to the oxide crystal structure as shown in Figure S1B-D, fresh and stretched cells while the Figure S1A shows the cross section of the Ti-ZnO film. A photoanode with an increase in material surface area enhanced dye loading capability, which could be ascribed 
from UV-visible adsorption spectra of devices, based on various surface area materials under the same film thickness, is shown in Figure 9. The photoanode composed of $\mathrm{Ti}(7.5 \%)-\mathrm{Zn}$ has a large BET surface area and sufficient dye-loading capability of $1.85 \times 10^{-7} \mathrm{~mol} \mathrm{~cm}^{-2}$, corresponding to their better light harvesting ability.

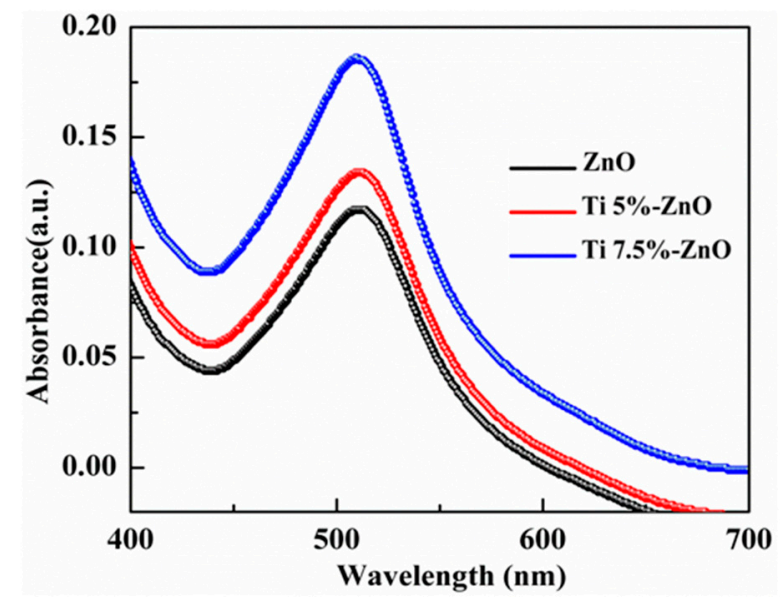

Figure 9. UV-Vis absorption spectra of DSSCs films based on $\mathrm{ZnO}$ and $\mathrm{Ti}(7.5 \%)-\mathrm{ZnO}, \mathrm{Ti}(5 \%)-\mathrm{ZnO}$.

\section{Conclusions}

In summary, $\mathrm{Ti}$ doped $\mathrm{ZnO}$ nanoparticles with mesoporous structure were synthesized via a simple synthetic route, and then successfully applied in dye-sensitized solar cells as a photoanode. It was found that $\mathrm{ZnO}$ nanoparticles decorated with $\mathrm{Ti}$ exhibited a superior light harvesting performance and the best efficiency of $5.56 \%$ could be obtained. Our experiments prove that the $44.7 \%$ photovoltaic performance enhancement can be possibly ascribed to the improved Fermi level and large surface area, which enhance dye loading ability, reduce charge recombination resistance and increase the harvest of photoexcited electrons. In conclusion the present work will provide a new route for the synthesis of efficient and unique working electrode materials.

Supplementary Materials: The following are available online at http:/ /www.mdpi.com/2073-4344/9/3/273/s1, Figure S1: SEM images of $\mathrm{ZnO}$ and $\mathrm{Ti}$ doped $\mathrm{ZnO}$, film thickness (A), $\mathrm{ZnO}$ stretched cell (B), Ti doped $\mathrm{ZnO}$ stretched and fresh cell (C, D), Figure S2: X-ray diffraction patterns of $\mathrm{ZnO}$ and Ti doped ZnO, with various percentage of Ti dopping, Figure S3: EDX of TZ samples (1, 2, 3 and 4), Figure S4: CVs of (a) Ti-ZnO and (b) ZnO, Figure S5: X-ray diffraction pattern of Ti(10\%)-ZnO, Table S1: Physiochemical properties of ZnO and TZ materials, Table S2: Elemental analysis of Ti percentage in TZ samples, Table S3: Optical and electrochemical properties of $\mathrm{ZnO}$ and $\mathrm{Ti}-\mathrm{ZnO}$.

Author Contributions: This research was a part of the PhD work of M.U.R. Under the supervision of M.W. The experimental work was carried out in Institute of Advanced Energy Materials, college of chemistry, Fuzhou University by M.U.R. under the supervision of M.W. M.U.R. wrote the manuscript, data analysis. F.X. and M.K. revised the manuscript. M.W. has done the technical supervision, and corresponding with journal for the manuscript.

Funding: This research received no external funding.

Acknowledgments: Qingqing Sun and Yafeng Li are acknowledged for there help with dye loading analysis.

Conflicts of Interest: The authors declare no conflict of interest.

\section{References}

1. Grätzel, M. Solar Energy Conversion by Dye-Sensitized Photovoltaic Cells. Inorg. Chem. 2005, 44, 6841-6851. [CrossRef] [PubMed]

2. Xiaoguang, M.; Swee Jen, C.; Benhu, F.; Jianyong, O. High-performance dye-sensitized solar cells with gel-coated binder-free carbon nanotube films as counter electrode. Nanotechnology 2010, 21, 395202. 


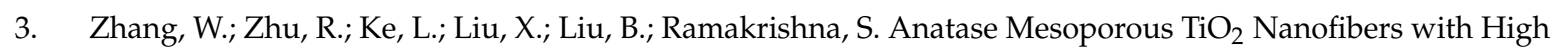
Surface Area for Solid-State Dye-Sensitized Solar Cells. Small 2010, 6, 2176-2182. [CrossRef] [PubMed]

4. Poudel, P.; Qiao, Q. One dimensional nanostructure/nanoparticle composites as photoanodes for dye-sensitized solar cells. Nanoscale 2012, 4, 2826-2838. [CrossRef]

5. Wu, M.; Lin, X.; Wang, T.; Qiu, J.; Ma, T. Low-cost dye-sensitized solar cell based on nine kinds of carbon counter electrodes. Energy Environ. Sci. 2011, 4, 2308-2315. [CrossRef]

6. Shao, F.; Sun, J.; Gao, L.; Yang, S.; Luo, J. Growth of Various $\mathrm{TiO}_{2}$ Nanostructures for Dye-Sensitized Solar Cells. J. Phys. Chem. C 2011, 115, 1819-1823. [CrossRef]

7. O'Regan, B.; Gratzel, M. A low-cost, high-efficiency solar cell based on dye-sensitized colloidal TiO 2 films. Nat. 1991, 353, 737-740. [CrossRef]

8. Wang, P.; Zakeeruddin, S.M.; Moser, J.E.; Humphry-Baker, R.; Comte, P.; Aranyos, V.; Hagfeldt, A.; Nazeeruddin, M.K.; Grätzel, M. Stable New Sensitizer with Improved Light Harvesting for Nanocrystalline Dye-Sensitized Solar Cells. Adv. Mater. 2004, 16, 1806-1811. [CrossRef]

9. Hendry, E.; Koeberg, M.; O’Regan, B.; Bonn, M. Local Field Effects on Electron Transport in Nanostructured $\mathrm{TiO}_{2}$ Revealed by Terahertz Spectroscopy. Nano Lett. 2006, 6, 755-759. [CrossRef] [PubMed]

10. Yella, A.; Lee, H.-W.; Tsao, H.N.; Yi, C.; Chandiran, A.K.; Nazeeruddin, M.K.; Diau, E.W.-G.; Yeh, C.-Y.; Zakeeruddin, S.M.; Grätzel, M. Porphyrin-Sensitized Solar Cells with Cobalt (II/III)-Based Redox Electrolyte Exceed 12 Percent Efficiency. Science 2011, 334, 629-634. [CrossRef]

11. Peng, M.; Cai, X.; Fu, Y.; Yu, X.; Liu, S.; Deng, B.; Hany, K.; Zou, D. Facial synthesis of $\mathrm{SnO}_{2}$ nanoparticle film for efficient fiber-shaped dye-sensitized solar cells. J. Power Sources 2014, 247, 249-255. [CrossRef]

12. Song, H.; Lee, K.-H.; Jeong, H.; Um, S.H.; Han, G.-S.; Jung, H.S.; Jung, G.Y. A simple self-assembly route to single crystalline $\mathrm{SnO}_{2}$ nanorod growth by oriented attachment for dye sensitized solar cells. Nanoscale 2013, 5, 1188-1194. [CrossRef]

13. Ramasamy, E.; Lee, J. Ordered Mesoporous $\mathrm{SnO}_{2}$ - Based Photoanodes for High-Performance Dye-Sensitized Solar Cells. J. Phys. Chem. C 2010, 114, 22032-22037. [CrossRef]

14. Bendall, J.S.; Etgar, L.; Tan, S.C.; Cai, N.; Wang, P.; Zakeeruddin, S.M.; Gratzel, M.; Welland, M.E. An efficient DSSC based on ZnO nanowire photo-anodes and a new D-[small pi]-A organic dye. Energy Environ. Sci. 2011, 4, 2903-2908. [CrossRef]

15. Xia, J.B.; Li, F.Y.; Yang, S.M.; Huang, C.H. Composite electrode $\mathrm{SnO} \sim{ }_{2} / \mathrm{TiO} \sim 2$ for dye-sensitized solar cells. Chin. Chem. Lett. 2004, 15, 619-622.

16. Chen, S.G.; Chappel, S.; Diamant, Y.; Zaban, A. Preparation of $\mathrm{Nb}_{2} \mathrm{O}_{5}$ Coated $\mathrm{TiO}_{2} \mathrm{Nanoporous}$ Electrodes and Their Application in Dye-Sensitized Solar Cells. Chem. Mater. 2001, 13, 4629-4634. [CrossRef]

17. Gubbala, S.; Chakrapani, V.; Kumar, V.; Sunkara, M.K. Band-Edge Engineered Hybrid Structures for Dye-Sensitized Solar Cells Based on $\mathrm{SnO}_{2}$ Nanowires. Adv. Funct. Mater. 2008, 18, 2411-2418. [CrossRef]

18. Prasittichai, C.; Hupp, J.T. Surface modification of $\mathrm{SnO}_{2}$ photoelectrodes in dye-sensitized solar cells: Significant improvements in photovoltage via $\mathrm{Al}_{2} \mathrm{O}_{3}$ atomic layer deposition. J. Phys. Chem. Lett. 2010, 1, 1611-1615. [CrossRef]

19. Qian, J.; Liu, P.; Xiao, Y.; Jiang, Y.; Cao, Y.; Ai, X.; Yang, H. TiO 2 -coated multilayered $\mathrm{SnO}_{2}$ hollow microspheres for dye-sensitized solar cells. Adv. Mater. 2009, 21, 3663-3667. [CrossRef]

20. Law, M.; Greene, L.E.; Johnson, J.C.; Saykally, R.; Yang, P. Nanowire dye-sensitized solar cells. Nat. Mater. 2005, 4, 455-459. [CrossRef]

21. Archana, P.S.; Jose, R.; Vijila, C.; Ramakrishna, S. Improved Electron Diffusion Coefficient in Electrospun $\mathrm{TiO}_{2}$ Nanowires. J. Phys. Chem. C 2009, 113, 21538-21542. [CrossRef]

22. Hosono, E.; Fujihara, S.; Kimura, T. Synthesis, structure and photoelectrochemical performance of micro/nano-textured ZnO/eosin Y electrodes. Electrochim. Acta 2004, 49, 2287-2293. [CrossRef]

23. Chen, M.; Wang, Y.; Song, L.; Gunawan, P.; Zhong, Z.; She, X.; Su, F. Urchin-like ZnO microspheres synthesized by thermal decomposition of hydrozincite as a copper catalyst promoter for the Rochow reaction. RSC Adv. 2012, 2, 4164-4168. [CrossRef]

24. Lin, L.; Yang, Y.; Men, L.; Wang, X.; He, D.; Chai, Y.; Zhao, B.; Ghoshroy, S.; Tang, Q. A highly efficient $\mathrm{TiO}_{2} @ \mathrm{ZnO}$ n-p-n heterojunction nanorod photocatalyst. Nanoscale 2013, 5, 588-593. [CrossRef]

25. Lee, D.; Rho, Y.; Allen, F.I.; Minor, A.M.; Ko, S.H.; Grigoropoulos, C.P. Synthesis of hierarchical $\mathrm{TiO}_{2}$ nanowires with densely-packed and omnidirectional branches. Nanoscale 2013, 5, 11147-11152. [CrossRef] 
26. Herman, I.; Yeo, J.; Hong, S.; Lee, D.; Nam, K.H.; Choi, J.-H.; Hong, W.-H.; Lee, D.; Grigoropoulos, C.P.; Ko, S.H. Hierarchical weeping willow nano-tree growth and effect of branching on dye-sensitized solar cell efficiency. Nanotechnology 2012, 23, 194005. [CrossRef]

27. Ko, S.H.; Lee, D.; Kang, H.W.; Nam, K.H.; Yeo, J.Y.; Hong, S.J.; Grigoropoulos, C.P.; Sung, H.J. Nanoforest of Hydrothermally Grown Hierarchical ZnO Nanowires for a High Efficiency Dye-Sensitized Solar Cell. Nano Lett. 2011, 11, 666-671. [CrossRef]

28. Yin, X.; Que, W.; Fei, D.; Xie, H.; He, Z.; Wang, G. Strategies to prepare an efficient photoanode for ZnO nanowires-based CdS-CdSe co-sensitized solar cells. Electrochim. Acta 2013, 89, 561-570. [CrossRef]

29. Keis, K.; Bauer, C.; Boschloo, G.; Hagfeldt, A.; Westermark, K.; Rensmo, H.; Siegbahn, H. Nanostructured ZnO electrodes for dye-sensitized solar cell applications. J. Photochem. Photobiol. A Chem. 2002, 148, 57-64. [CrossRef]

30. Han, Z.; Ren, L.; Cui, Z.; Chen, C.; Pan, H.; Chen, J. Ag/ZnO flower heterostructures as a visible-light driven photocatalyst via surface plasmon resonance. Appl. Catal. B: Environ. 2012, 126, 298-305. [CrossRef]

31. Lee, S.-H.; Han, S.-H.; Jung, H.S.; Shin, H.; Lee, J.; Noh, J.-H.; Lee, S.; Cho, I.-S.; Lee, J.-K.; Kim, J.; et al. Al-Doped ZnO Thin Film: A New Transparent Conducting Layer for ZnO Nanowire-Based Dye-Sensitized Solar Cells. J. Phys. Chem. C 2010, 114, 7185-7189. [CrossRef]

32. Kao, C.H.; Wang, J.C.; Lai, C.S.; Huang, C.Y.; Ou, J.C.; Wang, H.Y. Ti-doped $\mathrm{Gd}_{2} \mathrm{O}_{3}$ sensing membrane for electrolyte-insulator-semiconductor $\mathrm{pH}$ sensor. Thin Solid Films 2012, 520, 3760-3763. [CrossRef]

33. Wei, M.; Wang, K.; Yanagida, M.; Sugihara, H.; Morris, M.A.; Holmes, J.D.; Zhou, H. Supercritical fluid processing of mesoporous crystalline $\mathrm{TiO}_{2}$ thin films for highly efficient dye-sensitized solar cells. J. Mater. Chem. 2007, 17, 3888-3893. [CrossRef]

34. Pang, A.; Sun, X.; Ruan, H.; Li, Y.; Dai, S.; Wei, M. Highly efficient dye-sensitized solar cells composed of $\mathrm{TiO}_{2} @ \mathrm{SnO}_{2}$ core-shell microspheres. Nano Energy 2014, 5, 82-90. [CrossRef]

35. Rahman, M.u.; Ullah Wazir, H.; Khan, M.; Nosheen, S.; Rahman, S.; Ullah, A. Precursor-Induced Template free hydrothermal synthesis of Faujasite and its Application in Catalytic Pyrolysis. Mater. Res. Express 2017, 4, 055009. [CrossRef]

36. Xiao, Y.; Han, G.; Wu, J.; Lin, J.-Y. Efficient bifacial perovskite solar cell based on a highly transparent poly(3,4-ethylenedioxythiophene) as the p-type hole-transporting material. J. Power Sources 2016, 306, 171-177. [CrossRef]

37. Acharya, S.A.; Maheshwari, N.; Tatikondewar, L.; Kshirsagar, A.; Kulkarni, S.K. Ethylenediamine-Mediated Wurtzite Phase Formation in ZnS. Cryst. Growth Des. 2013, 13, 1369-1376. [CrossRef] 